\title{
Meeting the needs and expectations of retirees
}

\author{
Heather Nicolson-Morrison, Ec.D.
}

The growing population of baby boomers is affecting the demography in an entirely new way - unlike anything previously experienced in Canada. This paper analyzes the positive and negative factors of accommodating the current elderly population and suggests solutions to meet their needs that will have a positive benefit for the population overall. The author cautions that economic developers must prepare for the increasing demands on an already over-burdened infrastructure and health care system through local strategic planning directed at attracting and accommodating the housing, as well as, other needs of seniors.

Keywords: baby boomers, seniors, population, economic developers

Baby boomers, "those born in the 20 years after the Second World War, will have the most profound impact on Canada's population in the next 25 years”. ${ }^{1}$ This burgeoning group, known as the 'me' generation, is affecting the demography in an entirely new way - unlike anything previously experienced by our country. The economic developer can play a vital role in accommodating this phenomenon, which will magnify any challenges and difficulties hereto encountered within the current elderly population. It becomes imperative, therefore, to study the stratification of seniors within the social and financial infrastructure of a given community, to analyze the positive and negative factors which contribute to their placement, and to derive solutions that will meet their needs and have a positive benefit for the population overall.

One perspective that could be applied in evaluating the status of senior citizens is Maslow's Hierarchy of Needs. By beginning with an examination of their particular, physiological needs and progressing through safety issues, the human needs for love and companionship, for esteem and self-actualization, one grasps the framework of senior society. Furthermore, their income levels, health status, attitudes and lifestyles must be gauged. With this data, the economic developer can assist a community to prepare for the inevitable. By acknowledging the weaknesses and building on the strengths of seniors, alternate, cost-effective, financially feasible solutions can be explored and offered that will provide the group with some sense of worth. Moreover, the programs and strategies established and applied will attract a broader representation of this age group from outside the community and, in the process, produce positive economic spin-off effects.

Growth in the senior population and the need to provide specific services to accommodate the increase will affect areas such as job development, employment opportunities and available

\footnotetext{
${ }^{1}$ The Canadian Press, news service, press release, 2001.
} 
infrastructure. While the senior population is growing and their life span extending (75.7 to 79.5 for males and females respectively) ${ }^{2}$, the increase is not occurring in balance with the deceleration of the general population. Therefore, it is essential that society allows seniors to retain as much independence as possible and values their contribution, wisdom and experience.

\section{If you build it they will come}

Economic developers should focus on the needs of the business sector, as well as other segments capable of contributing to the growth and development prospects of the community. For years, statisticians and population forecasters warned about the expected growth of the senior population. Now, as the first of the 'baby boomers' reach 50 and are inclined towards early retirement, past projections have become a reality. A proactive approach by economic developers that includes attraction programs will position communities to benefit from the impact created by a growing population of seniors. The growing number of seniors (four million in 2000 to an estimated excess of more than eight million in 2026) ${ }^{3}$ represents a segment of the population with relatively high incomes and expectations. Some seniors want to maintain their independence by remaining in their neighbourhood home year round. Others prefer to move into smaller, more convenient accommodations within their communities. And, still others want to live in a more attractive, winter environment, staying in Canada for the amount of time prescribed by the particular province's interpretation of residency established in the Canada Health Act. All are searching for communities that are sensitive to the needs of seniors. Another, less independent group prefers to remain in their community in an institutional setting that is specifically designed for their needs, safety and mobility. Economic developers can assist in the creation of local opportunities geared to accommodate the demands of these groups.

By 2016 seniors will outnumber children 14 and under. ${ }^{4}$ The economic developer is but one of a number of facilitators responsible for meeting the special demands of seniors in their communities. Input from various professionals is required to develop strategies and consensus before approaching any level of government for funding. The economic developer should be directly involved in the development of local strategies designed to attract seniors to the community. Seniors, health and social work professionals, government and business must also be a part of developing these strategies. Involving the economic developer brings expertise in networking, as well as, effective, efficient, operational and skilled advice to the process.

It is reasonable to expect that the business community would want to partner with the economic developer in programs directed at attracting seniors into the community. Seniors, like the rest of

\footnotetext{
${ }^{2}$ Health Indicators, (Ottawa: Canadian Institute for Health Information, Statistics Canada, 1999) Map - Life Expectancy at Birth by Health Region, 1996.

${ }^{3}$ Canada's Seniors, Statistical Snapshots of Canada's Seniors, Statistics Canada for the Division of Aging and Seniors, (Ottawa: Government of Canada, 2001) No.1.

${ }^{4}$ The Canadian Press, news service, press release, 2001.
} 
the population, contribute to the local economy through expenditures on basics including food, shelter, clothing and transportation.

A mandate designed to promote a community as a location for seniors should include:

- the encouragement of local entrepreneurship by promoting the creation, expansion and attraction of businesses which provide for the needs of seniors;

- the fostering of local development opportunities that improve the community tax-base and local employment;

- the educating of the of the opportunities and challenges of an aging population;

- the understanding, that while certain segments of the senior population (snowbirds) travel, these people continue to pay taxes without imposing on the existing infrastructure.

The mandate can be met through activities that include:

- utilizing seniors as volunteers. Seniors contribute to community welfare by volunteering time, expertise and finances. In 1997, 800,000 Canadians aged 65 and over (23 per cent of the total senior population) participated in volunteer activities. ${ }^{5}$ "Aging Baby Boomers are a huge potential resource as members, donors and volunteers. To tap this resource, associations need to act, and frame their actions, in terms that will appeal to the higher sense of purpose in aging Baby Boomers. They will want to do something truly worthwhile and leave a legacy for the future"; 6

- providing community centres and activities that suit the interests and lifestyles of seniors. In 1996, it was reported that 20,000 seniors were back in school; one quarter of them were full-time students ${ }^{7}$. Approximately half of Canadian seniors are physically active on a regular basis; ${ }^{8}$

- focusing on seniors' needs in the areas of health, mobility and security by supplying or retrofitting local infrastructure, for example, the community swimming pool;

- acting as a strong advocate in the community by providing and/or cost sharing regional services and infrastructure, for example, a rehabilitation or daycare centre for seniors;

- $\quad$ supporting business activities directed at meeting the requirements of seniors;

- accepting and facilitating the return of seniors who reside outside the community for part of the year;

- $\quad$ analysing the housing availability for seniors, as well as, changing needs for accommodation.

\footnotetext{
${ }^{5}$ Canada's Seniors, Statistical Snapshots of Canada's Seniors, Statistics Canada for the Division of Aging and Seniors, (Ottawa: Government of Canada, 2001) No. 20.

${ }^{6}$ Anderson, Michael, “Get ready to Listen to the Future”, Association Magazine, April/May, 2001, Toronto, p. 8.

${ }^{7}$ Canada's Seniors, Statistical Snapshots of Canada's Seniors, Statistics Canada for the Division of Aging and Seniors, (Ottawa: Government of Canada, 2001) No. 20.

${ }^{8}$ Canada's Seniors, Statistical Snapshots of Canada's Seniors, Statistics Canada for the Division of Aging and Seniors, (Ottawa: Government of Canada, 2001) No. 49.
} 
A retiree community must respond to the physical challenges encountered by seniors, and, in the process, meet their specific needs. Shopping, health care, recreational facilities must be available. The National Advisory Council on Aging states that, "protection, promotion and prevention must take on higher priority - not only in health policy and programs but in other sectors as well, such as environmental protection, sports and recreation, housing and urban design, and all other broad determinants of health"9

The contribution of seniors to local economic development extends beyond establishing residency in the community. For instance, as a group, seniors prefer to travel within Canada. In 1997, an average of just fewer than three trips per person were taken within the country as compared to an average of 0.7 international trips. ${ }^{10}$ Given these observed preferences, the potential contribution of seniors to the local economy offered through tourism activity cannot be overlooked, especially when it has been estimated that 80 per cent of all import dollars in Ontario are generated by tourism.

Communities selecting to retain and expand their senior population base cannot proceed without adequate services ranging from doctors to health care. The identification of required services should be approached through a strategic plan based on a comprehensive needs assessment survey. Some of the benefits arising from the planning process include the identification of local business opportunities directed at serving seniors.

As a marketing initiative, a brochure could be developed to attract new senior residents to the community. Advertising directed at seniors to settle in specific locales, to purchase certain products and to live a certain lifestyle is quite extensive. Publications such as "Places to Retire in Canada" 11 are proving to be effective marketing tools for this purpose. The publication concentrates on what is affordable, comfortable and interesting to a retiree. It is important that new businesses or firms investigating the area be linked to the local network of real estate agents, mentor businesses and parallel associations. The opportunity also exists to participate in trade shows and to advertise in national and international trade magazines.

\section{Aging in place or Hell no! We won’t go! ${ }^{12}$}

In 1996, 93 per cent of all people over the age of 65 lived in private dwellings. ${ }^{13}$ A significant proportion of seniors have selected to retire in their communities and remain in the same house they occupied for years. This lifestyle is suitable for a healthy and independent segment of the

\footnotetext{
${ }^{9}$ Expression, Bulletin of the National Advisory Council on Aging, Ottawa: Government of Canada, Winter 2000 Volume 14, No.1, p. 9.

${ }^{10}$ Canada's Seniors, Statistical Snapshots of Canada's Seniors, Statistics Canada for the Division of Aging and Seniors, (Ottawa: Government of Canada, 2001) No. 36.

${ }^{11}$ Places to Retire in Canada Inc, ed. Greg Huneault, (Sudbury, 2001).

${ }^{12}$ Nicolson, H., “Hell no! We won't go!” CARP News, (Toronto Edition: Canadian Association of Retired Persons, 1996) Winter Edition.

${ }^{13}$ Canada's Seniors, Statistical Snapshots of Canada's Seniors, Statistics Canada for the Division of Aging and Seniors, (Ottawa: Government of Canada, 2001) No. 6.
} 
population. However, a community should provide alternative housing for those wishing to locate to accommodations that meet their specific physical and emotional needs. Public support for such projects requires a true understanding of the lifestyle demands of a senior population.

"With the technology and support available today, seniors must weigh their options and realize that they, unlike seniors of the past, do not have to forfeit the independence that they worked hard to achieve."14

Aging in place is a feasible and affordable alternative. Renovating with retirement in mind represents an investment for the future. As the 'boomers' age, homes that are constructed or renovated to facilitate mobility will be in demand and their value will hold and possibly increase.

Statistics show that 84 per cent of people 55 years and over prefer to remain in their own homes in their mature years. ${ }^{15}$ Currently, 76 per cent live in areas classified as urban. Furthermore, 68 per cent of all seniors who headed households were homeowners. ${ }^{16}$ Advances in medical technology have increased independent living for the aging and elderly and have made the prospect of remaining home a viable option. Many procedures and services once provided through hospitals or nursing homes are now offered through home-care agencies. And, with the responsibility for long-term care being passed on to the private sector, it is important that the viability of new initiatives, ideas, and creative solutions designed to meet future challenges is not threatened by excessively high costs.

What influences the decision to move to a new location or to renovate and remain at an existing location? These are personal decisions. Given the considerable expense measured both in financial and psychological terms, change is not always the appropriate alternative. The pressure often placed on the senior population to move at the first sign of difficulty can be avoided, especially since renovating can provide a cost effective, less stressful alternative. Many aging people prefer to remain in their community. In remaining in a familiar environment, the likelihood of disorientation often displayed due to the natural process of cerebral atrophy is minimized.

Consider the example of the Woods, a retired couple, living in Newmarket, a southern Ontario community, with a population of 65,000 . They live in the proximity of a hospital and all other medical amenities. Mrs. Wood was a head nurse at the local hospital and retired with a reasonable pension and RRSP's. Dr. Wood was a university professor, who, having entered his field later in life, retired with only old age and security pensions. They helped their three children through university. They have lived in the same mortgage-free home for 48 years. Friends,

\footnotetext{
${ }^{14}$ Information received by the writer in an interview with Robin Morrison, B. Arch., OAA in January, 1997 and May, 2001, on the various housing opportunities for seniors.

${ }^{15}$ American Association of Retired Persons, 1992.

${ }^{16}$ Canada's Seniors, Statistical Snapshots of Canada's Seniors, Statistics Canada for the Division of Aging and Seniors, (Ottawa: Government of Canada, 2001) No. 6.
} 
church and grandchildren are close by and the downtown core is within walking distance. These are all factors contributing to $a$ happy, comfortable retirement. With this in mind they planned carefully to remain in their home. Recently, however, Dr. Wood has had some medical setbacks and the couple has been forced to make a decision based on finances. They did not want to leave the community they cherish, nor a house they enjoy.

“I don’t want to relinquish this home towards which I have a tremendous sense of stewardship, it having belonged to our parents and witnessed four generations. As well I don't want to give up the comfort and security of the neighborhood.” 17

The couple is in a situation that is similar to that faced by numerous North American retired suburban couples. Their house, which was built in the 1940s, is a typical two-storey building. The basement contains the laundry, the freezer and storage facilities. The first floor has the living and dining rooms, kitchen and a small study. The second floor has the only washroom, and three bedrooms, one of which is used as an office. Due to decreased mobility, they are finding it increasingly more difficult to go up and down the stairs. As well, a more frequent need to use the washroom has increased the already mounting difficulties of staying in the home. Additionally, as consultants, they use the library on the first floor but must carry selections to the office on the second. They don't mind navigating the stairway, but it has become an unsafe, painful exercise.

The garden always provided enjoyment for the entire family. Dr. Wood is an avid gardener and bird watcher. The yard, located seven stairs down from the main level, is becoming more difficult and dangerous to access.

They do not want to leave their community and have decided to continue living in their home. They do not wish to feel displaced from their surroundings nor lose their independence. The house has been adapted for their specific needs - he is hearing impaired and enjoys music that is played loudly; she enjoys her kitchen and the decoration of the home. The layout of the house and the memories it holds are not to be forfeited. After much consideration they chose the simplest solution. With the help of a recommended architect, they looked at various renovation options and decided the best choice for their budget would be to install a washroom, laundry and a bed/sitting room on the ground floor. Initially, the area chosen for this renovation was the garage. However, due to changes in the street level and the increase in traffic in the neighborhood, it was determined that the garage was essential for future resale purposes. Consequently, they selected to simply add to the back of the house. A deck was designed off the new laundry facilities for easier and immediate access to both the yard and garbage/recycling storage. There was a change in their status, a daughter and son-in-law moved home to help with

\footnotetext{
17 Information received by the writer in an interview with Mrs. Wood and her architect at her home in Newmarket, in November,1997 and May/June, 2001, on her perspective as a senior facing a housing issue.
} 
the father's needs and the design was altered to renovate the upstairs into a private apartment.

"I believe I am taking a financial step that will increase our physical comfort and well-being, while avoiding the risk of a dramatic change that a move would entail." 18

\section{Moving and settling into new area}

\begin{tabular}{|l|l|l|l|}
\hline MOVING & $\begin{array}{l}\text { ASSOCIATED } \\
\text { COST }\end{array}$ & RENOVATING & $\begin{array}{l}\text { ASSOCIATED } \\
\text { COST }\end{array}$ \\
\hline Legal Fees* & & $\begin{array}{l}\text { Design \& } \\
\text { Construction }\end{array}$ & \\
\hline Sale & $\$ 550$ & Design Fees & $\$ 8,000$ \\
\hline Disbursements & $\$ 425$ & Construction Cost & $\$ 44,900 * *$ \\
\hline Purchase & $\$ 750$ & Contingency & $\$ 2,000$ \\
\hline Disbursements & $\$ 750$ & Building Permit & $\$ 100$ \\
\hline Real Estate Fee & $\$ 12,000^{* * *}$ & PST/GST & $\$ 460$ \\
\hline Transfer Tax Purchase & $\$ 2,225 * * * *$ & Lawyer's Fee & $\$ 500$ \\
\hline Additional Costs & $\$ 2,005^{* * * * *}$ & & \\
\hline Moving Costs***** & & & \\
\hline Moving Costs & $\$ 3,000$ & & \\
\hline Weight/mileage & $\$ 50 * * * * * * *$ & & \\
\hline Packing & $\$ 2,200$ & & \\
\hline Insurance & $\$ 200 * * * * * * * *$ & & \\
\hline Cleaning & $\$ 500$ & & \\
\hline Painting/Draperies & $\$ 4,000$ & & \\
\hline Telephone & $\$ 80$ & & \\
\hline Change of address & $\$ 100$ & & \\
\hline Cable installation & $\$ 50$ & & \\
\hline Sale & & \\
\hline
\end{tabular}

* $\quad$ Sale and legal costs based on $\$ 200,000$ to $\$ 250,000$ house with one mortgage

** $\quad$ Size of addition/renovation 14 feet X 28 feet

*** Agent fee of approximately five to six per cent

**** Land Transfer Cost (.01 X Purchase price -\$250)

$* * * * * \quad$ Additional costs can be in the thousands of dollars and are shown in a new house agreement. (i.e. Ontario New Home Warranty Plan, hydro and water hook-up, drive way paving and landscaping)

****** Moving - average cost of move for three bedroom house, prime time, three men eight to 10 hrs, truck to tractor trailer (\$120 per hour), excluding summer end of month

\footnotetext{
${ }^{18}$ Interview with Mrs. Wood, November 1997 and May/June 2001.
} 
moves

******* Weight/mileage - costs vary for weight of move and distance: e.g. 2,200 miles at $8,000-12,000 \mathrm{lb}$. is $136.36 \mathrm{X}$ per $100 \mathrm{lbs} .=\$ 1,363.60$

$* * * * * * * * .40$ per 100 lbs value

It should be noted that some real estate agents specializing in the senior market believe that contrary to logic, buying “down” by $\$ 50,000$ or less, i.e. selling a home for $\$ 250,000$ to purchase a home for $\$ 200,000$ in the same neighbourhood is not feasible. The $\$ 50,000$ anticipated equity gain can be eroded by the various fees. ${ }^{19}$

Craig Losell, partner at Hunter-Hill, Barristers and Solicitors states that,

"Having a purchaser take over or assume a mortgage has significant risks and should never be considered without reviewing the risks with a lawyer. Taking care when selling a home and terminating a mortgage is as important as shopping for the best interest rate when purchasing or refinancing.”

Alternatives need to be made available for seniors who wish to stay in their community but not in their existing home. Many want a retiree lifestyle that may include condominiums with a noyoung families policy, and property upkeep provisions, such as regular snow shovelling. Others may want to maintain an independent lifestyle with some assistance, for instance, health care and meal planning. Yet others require a more dependent lifestyle but still wish to remain in their community in facilities, such as nursing homes or other care units.

"I am very concerned that most municipalities and cities do not understand the specific building requirements of seniors. Simply put everything needs to be on one floor for ease of access. I realize most major cities due to the high price of land simply cannot afford to build one storey homes, however, many seniors do not want to live in high rise condo's but want access to their yard and their gardens." 20

Retirees must be educated and advised by reliable, qualified professionals such as financial advisors, real estate agents, lawyers, occupational therapists and architects of the available options. Feasible options must be available in the community if seniors are expected to take control of their future. Not everyone wants to renovate, sometimes it is easier to move. Seniors will remain in a community that provides housing options and is sensitive to their special needs.

\footnotetext{
${ }^{19}$ Information received by this writer in a telephone interview with Ms. Lori Armstrong, Caldwell Banker on 12 June, 2001 regarding resale value of homes.

${ }^{20}$ Information received by this writer in a conversation with Ms. Ellen White, P. Ed., Communications Secretary, Canadian Snowbird Association, on June 14, 2001 regarding accommodation for seniors.
} 


\section{Empty nest revisited -- what's love got to do with it? ${ }^{21}$}

In the 1960's, sociologists debated the death of the extended family with aunts, uncles and grandparents living under the same roof. Society encouraged children to become more independent. Due to the economic climate in the late 1980s and early 90s, the trend reversed: more marriages broke down; there was an increase in single parenting; and the country experienced recessions. Often children, and in some cases, a spouse with children, returned to reside at their parents' home. In some situations, the opposite occurred, where parents left their homes and moved in with their children to offer financial support or to provide care to grandchildren. And, rather than move away, many university students have, for financial reasons, selected to remain at home, or return for the summer and even after graduating. Furthermore, with the government downloading many services, women have increasingly been taking on the responsibility of caring for one or both parents. In 1996, 2.1 million adult Canadians provided support for one or more seniors; eighty percent of these caregivers were family members. Sixty one per cent were women who on average provided five hours of care giving per week; in comparison, men on average provided three hours or care giving per week. ${ }^{22}$ The bottom line is that by 1996 , at least seven per cent or $240,000^{23}$ seniors over 65 years were in households with two or more generations living under one roof.

They are back; the kids are here and it appears they will stay for a while. Unlike their parents before them, their homes lost equity and despite careful planning, there was never any real financial stability. Retirees and seniors are increasingly approaching professionals such as architects to explore their accommodation options. Issues related to lifestyles versus children's and housing needs are being discussed. Some of the building options available include: 1) reverse renovations or renovating to suit current needs with the option of being able to revert to the original use; or 2) adding an apartment or a granny flat to the home. Privacy and independence can become an issue, and all too often, routines are disrupted. Today many homes have separate entrances, more than one telephone and cable line, two car garages and sometimes two to three cars, and fenced yards that were once gardened.

Retirees achieve their independence by raising children, educating them, seeing them marry and leave home. In the process, the neighbourhood culture changes, as does, infrastructure needs. Older neighbourhoods settled into a comfortable routine suddenly face a new set of challenges with the return of mature children to the once empty nest. This unexpected change in social structure can influence the development and profile of not just a family but neighbourhood.

\footnotetext{
${ }^{21}$ Nicolson, H., “What's Love Got to Do With It?” CARP News (Toronto Edition: Canadian Association of Retired Persons, 1998) Spring Edition.

${ }^{22}$ Ministerial meeting in Ottawa with Business Women led by the Honourable Dianne Cunningham, Minister of Intergovernmental Affairs with Responsibility for Women's, Winter, 1996. The Minister was holding provincial round tables regarding the demanding role of women in business and society. Additionally, Health Care in Canada - A First Annual Report. (Ottawa: Canadian Institute for Health Information, 2000) pg. 60.

${ }_{23}$ Canada's Seniors, Statistical Snapshots of Canada's Seniors, Statistics Canada for the Division of Aging and Seniors, (Ottawa: Government of Canada, 2001) No. 7.
} 
Before retiree's can reach any decision regarding suitable housing, it is important for them to understand the implications attributed to different options. If the option is to have children moving back then they need access to local building information and understand the local bylaws.

In the past, these homes once met the needs of growing families, however, now they must be modified to meet the requirements of an extended second family. Robin Morrison, Architect, owner of Home Remedies Design and Construction, states that, "home modifications must not only be practical but can suit a life style, mode of living and budget." Suddenly the safety of small children, the noise of teenagers, added pets, odd working hours or an at-home office must be considered without jeopardizing seniors' safety, independence, mental well being and the culture of the neighbourhood.

Changes to the physical structure can be as simple as installing removable interior walls or building an addition to the house. Adjustments will be required for increased use of existing washrooms, laundry and kitchen facilities. Having renovations done professionally to meet the new demands will prove to be financially beneficial. Morrison suggests that, "a house with a small apartment can actually increase the value of the property. The demand for extended family living will increase due to demographic and economic pressures making any house with flexible living spaces more marketable.” It is important to take the time to plan with a professional to produce harmonious living relationships throughout. An extended family relationship can provide a number of benefits including a more intimate exchange between grandparents and grandchildren and a stronger community feeling.

\section{Snowbirds}

It is interesting to note that in order to attract the snowbirds, which represent a growing segment of the population that is estimated to be between 400,000 to $450,000^{24}$, the Economic Developer must support their leaving the country for as many as two to six months (see Appendix A). Although away from the community for part of the year, the fact remains that this segment of the population contributes to the local economy. They come from blue and white-collar backgrounds, have stronger than average incomes and are excellent community contributors. Although they do leave their community for a set time each winter, the community still stands to gain. Retirees pay taxes and continue to fund infrastructure that they only use part of the year. Smaller household items for their winter home are usually purchased in Canada and transported to the US in the fall. They purchase other services to use outside the country and yet are not in the country imposing demands on a community's already overworked Health Care System. Seniors, who are very susceptible to health risks, such as respiratory ailments and broken hips,

\footnotetext{
${ }^{24}$ Information received by the writer in an interview with Mr. Mark Simone, President and COO of Medipac International Inc., at Medipac Offices in North York on June 13, 2001 regarding snowbird issues.
} 
are simply not residing in the country during the winter months when flu is more rampant and slips and falls are more frequent.

\section{Attracting these birds back to your community ${ }^{25}$}

Q. Why do you return to the same Canadian community each spring? (Choose all that apply.)

$\Gamma \quad$ Returning to permanent home

Г Rent/monthly payments are economical

Г To stay close to family and friends

Г Want to be near doctor/hospital

$\ulcorner\quad$ Close to recreational facilities i.e. golf course

$\ulcorner\quad$ Climate

\section{Why do your return to the same Canadian community each spring? (Choose all that apply. $)^{26}$}

Returning to permanent home

\section{Rent/monthly payments are economical}

To stay close to family and friends

Want to be near doctor/hospital

Close to recreational facilities i.e. golf course

\section{Climate}

\section{1per cent}

7.1per cent

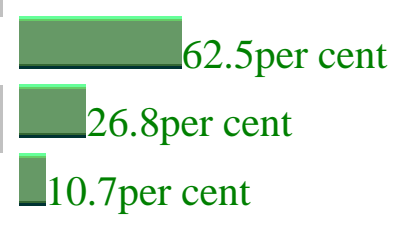

\section{6per cent}

"My reason for returning to St. Stephen (New Brunswick) each spring is quite simple. This is my home. I was born and raised here, raised my family here and have enjoyed a long and successful career in this town. Although we thoroughly enjoy and appreciate our winters south, there's still only one 'home' - and that's right here in New Brunswick.”,27

\footnotetext{
${ }^{25}$ Survey Question placed on the Canadian Snowbird Association Website on June 12, 2001.

${ }^{26}$ Survey Results as of June 25, 2001. Members and non-members can access and answer Snowbird surveys. Note: 58 submissions with a total of 126 votes: answer one 48 votes, answer two 4 votes, answer three 36 votes, answer four 16 votes, answer five 6 votes and answer seven 16 votes.

${ }^{27}$ Information received by this writer from Mr. Bob Jackson, former mayor of St. Stephen, former Cabinet Minister for the Province of New Brunswick, current president of the Canadian Snowbird Association on June 1, 2001 regarding what draws retirees back from the states to Canada.
} 
From the responses received it is apparent that the majority of these senior travelers return to their communities to be in their home and with their families; health care and climate seem to be a secondary issue.

\section{Long term care}

In 1997, 82 per cent of all seniors living at home reported a professionally diagnosed chronic health condition. ${ }^{28}$ Their chronic health problems related to arthritis and rheumatism, blood pressure, allergies, back problems, heart problems, cataracts, diabetes and a host of other ailments.

Seniors are far more likely to be hospitalized and remain in hospital longer than younger persons.

In 1996, seven per cent of all seniors $(245,000)$ lived in an institution. The majority of these, (85 per cent) lived in special care homes for the elderly or chronically ill. ${ }^{29}$

Health issues and costs will prevent some seniors from living independent lives. "The 1990s were a turbulent decade for health care in Canada, with changes in funding, management structures, and service organization and delivery... and the system no longer reflects today's demographics and social realities.”30 Communities need to carefully plan to accommodate those who need to reside in a fully or partially institutionalized setting. While current cost constraints are jeopardizing fully funded home-care, the cost of institutionalization is more excessive. A feasible plan is needed in the more immediate future. "If health care costs rise because of population aging, those same demographics will reduce costs in other program areas used more heavily by the younger members of the population (such as educational and correctional services). In short, just as government policy and public revenues accommodated sharp increases in housing, infrastructure and education in the post-war period, they should be able to adjust to meet future needs as priorities shift. ${ }^{31}$

\section{Conclusion}

The profile of most Canadian communities is changing radically. Depending on the extent of preparation the change will either have a positive or negative impact on communities. The population of seniors is increasing and demands on an already over- burdened infrastructure and health care system are becoming increasingly evident. Effective local strategic planning directed

\footnotetext{
${ }^{28}$ Canada's Seniors, Statistical Snapshots of Canada's Seniors, Statistics Canada for the Division of Aging and Seniors, (Ottawa: Government of Canada, 2001) No. 44.

${ }^{29}$ Canada's Seniors, Statistical Snapshots of Canada's Seniors, Statistics Canada for the Division of Aging and Seniors, (Ottawa: Government of Canada, 2001) No. 13.

${ }^{30}$ Expression, Bulletin of the National Advisory Council on Aging, Ottawa: Government of Canada, Winter 2000 Volume 14, No.1, p. 1.

${ }^{31}$ Denton, Frank T. and Byron G. Spencer, "Population aging and its economic costs: a survey of the issues and evidence.”, Canadian Journal on Aging, 19/supplement 1, Summer, 2000.
} 
at attracting and accommodating the housing, as well as, other needs of seniors will recognize the potential contributions and integrate this growing segment of the population into the socioeconomic structure of the communities.

\section{Author's biography}

Heather Nicolson-Morrison is the Executive Director of the Canadian Snowbird Association. Heather holds a general B.A. in Fine Arts, an honours B.A. in History, an M.A. in History and a Certificate and Diploma in Economic Development - all from the University of Waterloo.

Heather has been directly involved with economic development for the past 11 years. She has focused on strengthening communities through building relationships between business and community-centred groups and associations.

Heather was the senior policy advisor to Dianne Cunningham, Ontario Minister of Intergovernmental Affairs with Responsibility for Women. She was responsible for overseeing the development of policies and procedures in the ministry's two key areas of responsibility: promoting women's economic independence and preventing violence against women. Later, as senior policy advisor to Margaret Marland, Ontario’s first Minister Responsible for Children, she was involved in the design of a Challenge Fund, which worked at both the community and provincial level. These Challenge Fund projects involved partnerships and were established with the long-term goal of strengthening communities. Prior to this Heather was, for six years, the Executive Administrator/Economic Developer for the Newmarket Chamber of Commerce.

\section{Bibliography}

American Association of Retired Persons - 1992.

Canada's Seniors, Statistical Snapshots of Canada's Seniors, Statistics Canada for the Division of Aging and Seniors, Ottawa: Government of Canada, 2001.

Consumer Fraud and Seniors, Ottawa, Minister of Supply and Service Canada for the National Advisory on Aging, 1991.

Denton, Frank T. and Byron G. Spencer, "Population aging and its economic costs: a survey of the issues and evidence.” Canadian Journal on Aging. 19/supplement 1, Summer 2000.

Expression, Bulletin of the National Advisory Council on Aging, Ottawa: Government of Canada, Winter 2000, Volume 14, No.1. 
Gray, Douglas, Canadian Snowbird Guide, (2 ${ }^{\text {nd }}$ Edition), Toronto: McGraw-Hill Ryerson, 1997.

Kiedrowski, J., and C.H.S. Jayewardene, Writings in Gerontology. Public Safety and Seniors, Ottawa: Minister of Supply and Service Canada for the National Advisory on Aging, 1994.

Michael Anderson, “Get ready to Listen to the Future”, Association Magazine, Toronto, April/May 2001.

Nicolson, H., “Hell no! We won’t go!” CARP News, Toronto: Canadian Association of Retired Persons, 1996 Winter Edition.

Nicolson, H. "What's Love Got to Do With It?” CARP News, Toronto: Canadian Association of Retired Persons, 1998, Spring Edition.

Places to Retire in Canada Inc, ed. Greg Huneault, Sudbury, 2001.

Statistics Canada, Health Care in Canada. - A First Annual Report. Ottawa: Canadian Institute for Health Information, 2000.

Statistics Canada, Health Indicators, Ottawa: Canadian Institute for Health Information, 1999.

The Canadian Press, news service, press release, 2001.

Wigdor, Blossom, Elder Abuse: Major Issues From a National Perspective, Ottawa: Minister of Supply and Service Canada for the National Advisory on Aging, 1991.

\section{Interviews and meetings}

Ms. Lori Armstrong of Caldwell Banker, Newmarket, Ontario telephone interview on 12 June, 2001.

Mr. Jim Carney of Rawlinson Moving and Storage Mississauga with Allied Van Lines, June, 2001.

Honourable Dianne Cunningham, Minister of Intergovernmental Affairs with Responsibility for Women’s comments at Ministerial Roundtable in Ottawa, winter, 1996.

Honourable Robert Jackson, former mayor of St. Stephen, former Cabinet Minister for the Province of New Brunswick, current president of the Canadian Snowbird Association on June 1, 2001. 
Mr. Craig Losell, partner, Hill-Hunter Barristers and Solicitors, in November, 1996 and May, 2001 at his office in Newmarket, Ontario.

Mr. Robin Morrison, B. Arch., OAA, in January , 1997 and May, 2001 in North York, Ontario, regarding various options for housing for seniors.

Ms. Barbara Moss, Public Relations/Communication Advisor to the Canadian Snowbird Association at Head Office in North York on June 1, 2001.

Mr. Mark Simone, President and CEO of Medipac International Inc., at Medipac Offices in North York, Ontario on June 13, 2001.

Ms. Ellen White, P. Ed., Communications Secretary, Canadian Snowbird Association, on June 14, 2001 at the Canadian Snowbird Headquarters in North York, Ontario.

Mrs. Wood at her home in Newmarket, in November, 1997 and May/June, 2001, regarding her perspective as a senior facing a housing issue.

CSA Website Survey Question placed on site June 12, 2001. Reading taken June 25, 2001.

\section{Appendix A}

\begin{tabular}{|l|l|l|}
\hline Jurisdiction & $\begin{array}{l}\text { Annual Requirements for } \\
\text { Presence within the Province in } \\
\text { Order to Maintain Health Care }\end{array}$ & $\begin{array}{l}\text { Provinces Allowing } \\
\text { Additional Travel Within } \\
\text { Canada }\end{array}$ \\
\hline British Columbia & 183 days & X \\
\hline Alberta & $\begin{array}{l}\text { Maintain principle residence }- \\
\text { no stipulated number of days }\end{array}$ & $\mathrm{X}$ \\
\hline Saskatchewan & 183 days & $\mathrm{X}$ \\
\hline Manitoba & 183 days & $\mathrm{X}$ \\
\hline Ontario & 153 days & \\
\hline Quebec & 183 days & $\mathrm{X}$ \\
\hline Nova Scotia & 183 days & \\
\hline New Brunswick & & $\mathrm{X}$ \\
\hline Prince Edward Island & 183 days & \\
\hline Newfoundland & 4 months & \\
\hline Northwest Territories & 183 days & \\
\hline Yukon Territories & 183 days & \\
\hline
\end{tabular}

Note: This material was researched by Ms. Barbara Moss, Public Relations/Communication Advisor to the Canadian Snowbird Association, and provided on June 1, 2001. 